\title{
A Comparison Study of Military's Role in Democratization in Myanmar and Indonesia
}

\author{
Nian Peng \\ Government and International Relations \\ Hong Kong Baptist University \\ Hong Kong, China \\ jixi2212@163.com
}

\begin{abstract}
This paper argues that the degree of the cohesion of military is a determined factor in the democratization in Myanmar and Indonesia when they faced similar pressures. The strong cohesive military eventually prevented the facilitation of democratization in Myanmar, while the weak cohesion within the army caused their accommodation behaviors towards the democratic movements.
\end{abstract}

Keywords - Military; Democratization; Myanmar; Indonesia; Cohesion

\section{INTRODUCTION}

The past decades have witnessed several waves of progress and setback of democratization in Southeast Asia countries, during which the military played an important role. Some scholars argued that the military irredeemably impeded democracy, while others rebutted that the generals promoted the democratization. Those who hold the first stance stated that the dictatorial nature of military, such as discipline and loyalty within a hierarchy, determined its' anti-democracy stance, thereby undermined the democracy. As Agbese stated, military leaders conducted their transition programs in an antidemocratic manner [1]. Although this explanation reveals partial reasons that the military hostile to democracy, the bias against democracy can not explain how the military hamper the democracy. Given this, some scholars try to find the precise ways adopted by the military to block the democracy, among which Roth observed that when the generals inhibit the development of political parties, prohibit elections, or prevent other political bodies from operating, they retard political institutionalization [2] which is a key element in democracy.

Scholars belongs to the second school refuted that the negative depiction of the military was just a one side story. Actually, it was a two side story. On the one hand, the army can act to hold back democratization, on the other hand, it can also intervene to push democratization forward [3]. In terms of it, Jun Honna agreed that the military can either repress or accommodate the democratic demands from the mass [4]. To be specifically, the prodemocracy groups can align with the reformers within the army to against the military rule. Further, they explored different ways that the military positively engaged in the democratization. The first approach was the division within the military by which the prodemocracy groups can align with the reformers within the army to against the military rule. After the democracy was built, the generals and civilians need to consolidate the civilian supremacy, while forging the army's professionalism and allowing their voices in the security policies [5]. Alternatively, the military can also promote the political institutionalization and pave the way for democracy. For instance, the generals can transform their military rule to a semi-military rule or a civilian rule by organizing political parties and holding elections, though they may neither free nor fair.

Last but not least, except the previous two viewpoints, there still has a third explanation. Neither impede nor promote the democracy, the military seems to be neutral in the democratization. According to Huntington, objective civilian control could be achieved by maximizing military professionalism, which involves the recognition of an independent military sphere within the government and a clear distribution of power between the military and civilians [6]. In other words, if the military is 'professional' in the sense that its chief priority is to safeguard the national security against the external threats or invasions, it's more likely to isolate from politics, and therefore keep neutral stance in democratization.

By and large, although the present literature reveals some significant aspects of the role of military in democratization, it is lack of the analysis of the reasons that causes army's different reactions to democracy, and thus lead divergent results of democratization. Given this, this essay, by comparing military's role in democratization in Myanmar and Indonesia, argues that the degree of cohesion of military was a determined factor in democratization. It starts by briefly introducing background of this research before turning to analyze the similar pressures faced by the military and distinct results of democratization in Indonesia and Myanmar in 1998 and 2003 respectively. Then it probes into the determining factor which means the cohesion of military in Myanmar and Indonesia. After that, the article continues to go deeper into the cohesion of military and the democratization in Myanmar since 2003 and finally draws a conclusion.

\section{GREAT PRESSURES AND HARSH SUPPRESSION IN MYANMAR}

Myanmar and Indonesia military faced similar pressures in 2003 and 1998 respectively. For Myanmar, it had suffered 
great inside and outside challenges in 2003. Domestically, Aung San Suu Kyi, the leader of the opposing party-National League for Democracy (NLD) began to call for the resumption of political dialogue since she was released from house arrest in May 2002. However, her demands were rejected by the junta, which triggered a confrontational approach resorted by the NLD leaders. From June 2002 to May 2003, Aung San Suu Kyi together with other leaders toured though the countryside and encouraged the local people joining the political activities and supporting NLD. The overt political engagement caused the anti-NLD pamphlets and eventually triggered a blood clash between the anti-NLD protests and the NLD supporters in May 2003. Further, the collapse of several local private banks in February 2003 caused a worst bank crisis in Myanmar which undermine its economic performance, as well as the local and foreign business community's trust in the government [7]. Externally, the EU extended sanctions against Myanmar in March 2003 and the US also banned all imports from Myanmar after the clash in May 2003 [8].

Although faced great stresses internally and externally, the Burmese generals suppressed harshly towards the democratic supporters. After the blood riots in May 2003, the junta placed Aung San Suu Kyi under house arrest, detained a number of NLD leaders, and closed NLD's offices in Myanmar [9]. Although the junta unveiled a seven-point roadmap for democratization and pledged to reconvene the National Convention in May next year, it rejected NLD' demands for free discussion of political issues at the National Convention which finally caused the boycott of the NLD [10]. The adjourning of the National Convention in July 2004 brought a stalemate to the democratization in Myanmar.

\section{THE COHESION OF MILITARY IN MYANMAR}

In this part, I will demonstrate that the strong cohesion of military was the main obstacle in democratization in Myanmar. For the Burmese generals, building a strong, patriotic, cohesive and modern army has always been the top priority. Since the fighting for independence during the Second World War, the Burmese military leaders strived to construct a strong patriotic ideology within the army. Aung San, the father of the Tatmadaw as well as an honest patriot, addressed to the Burma Army on 1 March 1947, "The efficiency of Army does not dependent merely on the good equipment it is provided with but also on the will, spirit and discipline of those who compose it [11]." His successor Ne Win, one of the "Thirty Comrades", has persisted to enhance the cohesion of the Tatmadaw through implanting the patriotic ideology in commanders and soldiers. Even if he stepped down in 1988, the new chief general of the Tatmadaw, initially General Saw Maung and then General Than Shwe, still inherited the legacy of him. What's more, the new leaders further facilitated the patriotic doctrines in the Burmese army. Actually, Than Shwe, an extremely nationalist as well as a patriot, emphasized more on the patriotic propaganda not only in the Tatmadaw but also in the society than Ne Win. In 1997 when he addressed at the 52nd Anniversary Armed Forces Day, he stated "As it was the rallying point of patriotic youths, it fitted into the good tradition of a patriotic Tatmadaw [12]." In another speech at the 55th Anniversary Armed Forces Day Parade in March
2000, he stressed on the twelve Noble Traditions of the Tatmadaw, in which the first one is "A Patriotic Tatmadaw" [13].

Not only did the Burmese generals implement the patriotic propaganda, they built and strengthened the hierarchy within the army to consolidate the Tatmadaw. As Maung Aung Myoe, a renowned Myanmar expert observed, at least among some senior commanders, there is a tradition in the Tatmadaw to regard some former commanders as parents. Even at the battalion or regional level, the commanding officer and his wife are usually regarded as parents of the unit [14]. To be sure, Aung San, after his assassination before the eve of the independence of Burma in 1948, was memorized as the father of Tatmadaw as well as the independent Burma. Since then the tradition of respecting the former military leaders as parents has been bolstered. In fact, this old tradition has also been manifested in many military offices in Myanmar where three oversized photographs, General Aung San in the middle, General Ne Win on his left and General Than Shwe on his right, hang on the wall.

This disciplined hierarchy based on the strong personal ties seems to be a big family in which the chief commander is the oldest father and thus possesses the supreme authority to manage the whole family. This organizing style, as many analysists figured out, can ensure the loyalty of the soldiers and avoid any split of the army caused by the uncontrolled factional competitions. Actually, the most worrisome challenges to the Burmese generals were the severe factional conflicts beyond control [15]. Therefore, despite of the persistent factional struggles within the military, the contests were controlled effective by a strong person, the oldest father in the family. In 1997, General Than Shwe became the most powerful figure in Myanmar after the junta was transformed to State Peace and Development Council (SPDC). By retiring and purging many senior military officers and placing his loyalists in important positions, the military government became more coordinated and more unified [16] . As Rogers, the author of "Than Shwe: Unmasking Burma's Tyrant", investigated "Than Shwe has for many years been largely responsible for the career development of senior ranking officers, and has promoted young, handpicked soldiers, thereby hoping to earn lifetime loyalty [17]." In 2001, Than Shwe relieved Khin Nyunt, a reform-minded high official in military, as the head of the Office of Strategic Studies (OSS) and made a regional commander, Shwe Mann, his follower [18]. In March 2003, Soe Win, another supporter of Than Shwe, was appointed to the powerful position of Secretary II . There was also a rumor that Than Shwe placed another close ally, General Shwe Mann, in charge of military affairs. Meanwhile, Khin Nyunt, the reformer or moderate in military, appeared to be losing power [19]. Indeed, after several cabinet shuffles since 1997, the hard-liners totally dominated the military. As Renaud Egreteau and Larry Jagan observed, the year 2003 had already revealed the aversion of the army hardliners to any more political compromises [20].

Besides, the Tatmadaw introduced institutional measures and mechanisms to keep the military away from communal and factional struggle [21]. Ever since the creation of the Tatmadaw, the two pioneering training colleges including 
Defence Services Academy (DSA) and Officer Training School (OTS) has enrolled and educated a large number of junior military officers. Some of them, for instance, Than Shwe who graduated from the OTS, eventually became the chief commander of the Tatmadaw. Another capable general, Maung Aye, the DSA graduate, finally serviced as the deputy chief commander of the Tatmadaw as well as the second most senior general after Than Shwe. According to Maung Aung Myoe's investigation, as a 30-year manpower plan was hastily implemented in a short span of 12 years between 2000 and 2012 , the DSA alone produced a total 22,983 officers. If we add the officers commissioned through the OTS, more than 30,000 officers were commissioned during this period [22]. Four years after commissioning, these officers become captains and after another five years, they are due for promotion to the rank of major [23]. Through this institutional arrangement, the senior generals can be assured that all of the senior, middle and junior officers are in the one same hierarchical community, in which loyalty rather than betray can bring persistent benefits. Nonetheless, the rivalry between OTS and DSA graduates, has been matched by a divide between field commanders and military intelligence [24]. However, since the remove of Khin Nyunt, the chief director of the military intelligence as well as the excellent graduate of OTS, from the head of the OSS, the core agency within the military intelligence, in 2001, the commanders seem to be the final winners in the long-standing competition. The Tatmadaw, therefore, consolidated more than ever.

Undoubtedly, by using the patriotic propaganda, constructing the disciplined hierarchical army and introducing the institutional mechanisms, the Tatmadaw became more unified than before. As a result, the unified military can respond firmly to the democratic movements leaded by NLD. In fact, when Aung San Suu Kyi asked for the resumption of political dialogue after her release in May 2002, the military rejected strongly, even if the reformer Khin Nyunt also followed the order of the government. What's more, when dealing with the clash in May 2003, the military kept an unified stance and suppressed harshly towards the democratic supporters.

\section{RULING CRISIS AND COLLAPSE OF DICTATORSHIP IN INDONESIA}

Similarly, General Soeharto who seized power in 1965 in Indonesia also faced mounting stresses from domestic democratic demands and external critiques before 1998 . Firstly, the growing public discontents with the regime's ousting of Megawati, the leader of the democratic movement, derived strong demands for substantial reform of the government in the mid-1997 [25]. Secondly, the Southeast Asia economic crisis broke out in July 1997 hurt the Indonesia heavily and promoted the public resentments towards Soeharto Consequently, the increasing dissatisfactions in both politic and economy eventually evolved into persistent blood riots throughout the country and undermined the legitimacy of Soeharto`s government seriously. As Bird observed, the sense of political and economic drift into crisis in late 1997 severely eroded the authority of the leadership in Indonesia [26].
Externally, the Indonesia government has been under strong external stresses to restraint the role of military in politics [27].

Under the strong internal and external stresses, Soeharto, first of all, made leadership changes aiming to control the situation at the general session of the People's Consultation Assembly in March 1998. Two months later, he accepted the reform demands from the public, however, it was too late. His supporters, initially the Golkar, and then the parliament, finally the military overtly asked for his resignation. Abandoning by the ruling party, parliament and most importantly, the military, Soeharto had no choices but to resign. After the step down of Soeharto, the democratization in Indonesia was accelerated. In 2001, Megawati, the leader of the democratic movement became the president, and eventually Indonesia had a Presidential election in 2004.

\section{THE COHESION OF MILITARY IN INDONESIA}

As with most military regimes, increasing the cohesion and discipline of the armed forces has always been the major duty for the senior generals. To achieve this difficult goal, the military leaders employed various tools and mechanisms including the patriotic propaganda, the constitutional mechanisms and personal loyalty. First of all, aiming to consolidate the unity and discipline of the army, the patriotic doctrine has been frequently used by the Tentara Nasional Indonesia (TNI), the armed forces in Indonesia. As Angel Rabasa and John Haseman who owned the book "The Military and Democracy in Indonesia: Challenges, Politics, and Power" indicated, the Indonesian military officer corps is taught from the very first that the TNI as an institution is the foundation and guardian of national unity, a role that can only be carried out through unity in purpose and disciplined application of leadership [28].

What's more, the senior generals in Indonesian has also established a series of mechanisms to institutionalize the army. Firstly, The Indonesian military developed an ideological and legal framework to support a formal role in political affairs, named dwifungsi, or dual function. This concept held that the military had a "sociopolitical" as well as a defense function and gave the military an institutionalized role in politics [29]. However, not only did the democrats criticized the dwifungsi heavily, the reformers within the TNI were also anxious about the involvement of military in politics. Secondly, like the Tatmadaw in Myanmar, the military leaders in Indonesia also installed a number of different kinds of military schools aiming to enroll and educate the junior officers. After graduation, these junior officers are likely to possess a more advanced position after associating with more senior rank for many years. Only very limited number of graduates have opportunities to be nominated as senior generals.

Despite of the ideological propaganda and the institutionalization of the army, the TNI faced serious power struggles and thus undermined its cohesion and unity. As Jun Honna stated, the debates within the military not only reflected and facilitated intra-military rivalry, but also effectively eroded military's credibility, reaching a nadir at the time of Soeharto's resignation[30]. In fact, a few of reasons can explain the decreasing cohesion of the NTI. First of all, as 
Indonesia's economy began to achieve a rapid growth in the mid-1980s and beyond, the TNI began to lose the top level of high-school graduates, who changed their perception of the best path to success from the TNI to the business world [31]. Consequently, on the one hand, the further development of the military was affected because of the capability of absorbing the elites into the army was undermined, on the other hand, more and more top level graduates from the excellent military high schools became businessman and thereby enlarged the new business class outside the army. Although the new expanding business circle was not necessarily to resist the authoritarian regime, it perceived as the core precondition for democratization, as many democrats claimed.

Moreover, the potential for cracks in the TNI's unity comes from not only outside influences but also from fundamental elements of the military culture itself [32]. For one thing, outside the TNI, different political parties actively competed for their supporters within the senior TNI generals, which split the army into distinct blocs, for another, the factionalism based on the personal loyalty within the TNI also eroded the unity of the army. To avoid the cracking crisis within the army, Soeharto deliberately maintained a balance of the military leadership by adopting quickly personal transfers and the continuing rejigging of military leadership. The creation and cultivation of intra-military competition ensured that no camp within the armed forces grew strong enough to challenge Suharto's presidency [33]. However, his delicate tactics caused a persistent anti-Soeharto power which not only includes the high ranking generals but also the middle and low level military officers. In 1993, general Hartas claimed that the military would not suggest the re-election of Soeharto and another general Yunus overtly criticized Soeharto's govern in Indonesia in 1998 [34]. The intensified power rivalry achieved a peak in the 1997 general election. As Marcus Mietzner pointed out, catalyzing already existing differences between senior generals, the debate concerned the extent to which the armed forces were prepared to support Golkar in the upcoming polls [in 1997] [35]. One year later, followed by the competition of Golkar, the struggles for the candidate for vicepresident were intensive between Soeharto's followers and the oppositions within the military. Although Soeharto successfully appointed his supporter Habibi as the vicepresident in March, the discontents within the military were growing. In May 1998, in spite of the resists from Soeharto's hardliners who try to protect the old regime from reform, initiatives of adaption in both doctrinal dimension and civilmilitary dialogues were gradually taken by reform-minded officers [36]. Finally, the military chose to accommodate the public willing and pressed for the resignation of Soeharto. After the step down of Soeharto, the military focused on enhancing the cohesion rather than grasping the political power, which ensured the smooth development of democratization in Indonesia to the large extent.

\section{THE COHESION OF MILITARY AND DEMOCRATIZATION IN MYANMAR SINCE 2003}

After the riots in May 2003, Than Shwe nominated his followers Soe Win and Thein Sein to Secretary 1 and Secretary 2, which enhanced the strength of hard-liners sharply while reduced the power of Khin Nyunt dramatically. Ten months later, Khin Nyunt was eventually purged and his intelligence kingdom was also collapsed. The military thereby became more unified than before. Following the dismissal, Than Shwe's loyalists Soe Win and Thein Sein were appointed the new prime minister and Secretary I respectively. In spite of the new government's commitment to the "Seven Point Roadmap", the democratization in Myanmar was caught in a deadlock. The SPDC, after the cabinet reshuffle, moved to reassert total control of the nation's political, economic, and social life [37]. During the next few years, the senior generals focused on the consolidation of their rule in the government as well as in the military. In May 2006, the SPDC initiated major ministerial shuffles in the cabinet and made a total of 32 ministries under it [38]. Meanwhile, a number of military officers including the chief of Air Defense, chief of Military Affairs Security, Seven regional commanders, division commanders and regional operational commanders were promoted from January to August, which reflecting the SPDC's attempt to ensure institutional continuity through the recruitment of younger military officers [39]. At the same time, the government continued to take actions to suppress the antigovernment movements, which eventually triggered the "Saffron Revolution" lead by the Burmese monks in September 2007. Almost one month later, PM Soe Win, a hard-liner within the SPDC died, Thein Sein was appointed as his successor.

Since Thein Sein came to office, the democratization was started to accelerate. In May 2008, the SPDC hold referendum on a new constitution and get "yes" with majority voters. In the next three years, Myanmar held a general election in 2010, though it was perceived neither free nor fair, and inaugurated a civilian government in March 2011. In April 2012, the NLD, for the first time after the 1990 election, was allowed to participate in the by-election. Since then, various democratic parties took part in the political activities legally, the political prisons were released and the censorship was also relieved. Eventually, the NLD won a landmark victory in the landslide free and fair election in November 2015, and established a new democratic government in March 2016.

By analyzing the process of democratization since 2003, we can learn that the truly acceleration of democratization was in Thein Sein's era, especially when he was elected as the president in the civilian government in 2011. In fact, the rivalry among the senior leaders, particularly the president Thein Sein and parliament speaker Shwe Mann, and the competition between the government and the military agencies seems to be intensified in Thein Sein's presidency, which definitely undermined the cohesion of the military.

According to numerous analysis and reports inside and outside Myanmar, there was a long power competition between Thein Sein and Shwe Mann since they were promoted to the high ranking generals. Shwe Mann, the most loyal followers of Than Shwe, was likely to be elected as president in the 2010 election, but failed in the end. Nonetheless, Shwe Mann occupied significant positions including speaker of the parliament and chairman of Union Solidarity and Development Party (USDP), the ruling party, which made him have advantages in competing with Thein 
Sein. By controlling the parliament, Shwe Mann imposed certain pressures to the Thein Sein government, so did the USDP. What's more, Shwe Mann had contacted with Aung San Suu Kyi, the leader of NLD secretly, attempting to obtain some support from the opposing parties. Before the eve of the coming election in November 2015, Shwe Mann claimed several times that he would run for the president. However, he and his follower Maung Maung Thein were replaced by the supporters of Thein Sein in the USDP in August 2015, just three months before the election, which overtly delivered the sign of spiting of the junta. After the reshuffle in the ruling party, Shwe Mann engaged in cooperating with NLD openly, the most powerful opponent for USDP in the election, which eventually brought the definite break up between Shwe Mann and the junta.

In addition, like the most military regimes, the rivalry between the government and military has always been the great challenge for the rulers. In Myanmar, there is a long tradition within the military that the Tatmadaw should involve in the politics because the army is the safeguard of the nation. Given this, even if the civilian government was functioned in 2011, the important positions, especially the defense minister, border affairs minister and domestic affairs minister, were occupied by the generals or the retired generals. Additionally, the military possesses one quarter of the seats in the parliament, aiming to prevent any harmful acts that would hurt the interests of the army passed in the parliament. This deliberate arrangement, on the one hand, ensured military's control of the country, caused the competition between the government officials and military officers on the other. Since Thein Sein serviced as the president, the debates on the national reconciliation and the democratization between the civilian government and the Tatmandaw seems to be salient. For instance, the government's peaceful talks with the ethnic armed forces had been break up several times by the military operations launched by the Tatmandaw, which caused the government's dissatisfactions with the military. Besides, through appointing the high ranking military officers to the significant positions in the government as well as the USDP, the military continued to expand its influences on the politics and thus manipulated the pace of the democratization. However, military's attempt was resisted by Thein Sein who initiated a cabinet reshuffle in July 2012. Vice president Tin Aung Myint Oo, a conserver within the Tatmandaw resigned, and three other ministers were replaced by the reformers, which changed the balance between the conservers and reformers within the government and thus accelerated the economic and political reform. Again, around in August 2015 before Shwe Mann was dismissed, the USDP selected only 59 of 159 senior officers who retired from the military to stand, which likely angered officers and politicians keen to preserve the military's sway [40]. Soon after the decision, Shwe Mann was ousted from his post, the new chairman accepted all the 159 retired senior officers, which made the military officers in the majority in the central committee of the USDP. All in all, the rivalry among the senior government officials and the power struggle between the government and the military partially contributed to the crushing defeat suffered by the USDP in the 2015 election.

\section{CONCLUSION}

For many theorists of democratization, the role of military, positively, neutrally or negatively, is extremely important. This study, by probing into the comparison study of democratization in Myanmar and Indonesia, reveals that the degree of the cohesion of military is a determined factor in the democratization in Myanmar and Indonesia. The strong cohesive military eventually prevented the facilitation of democratization in Myanmar, while the weak cohesion within the military caused their accommodation behaviors towards the democratic movements and finally promoted a democratic regime in Indonesia. What's more, this essay also demonstrates that the decreasing cohesion of military caused by the rivalry in the senior generals accelerated the democratization in Myanmar.

\section{ACKNOWLEDGMENT}

This is an original academic paper presented during the international conference held at the Yunnan University of Finance and Economics on November 19-20, 2016.

\section{REFERENCES}

[1] Agbese, "Military as an obstacle to the democratization enterprise: toward an agenda for permanent military disengagement from politics in Nigeria," vol. 31, Journal of African and Asian Studies, 1996, pp. 90-91.

[2] D.F. Roth, "Comparative politics: divers states in an interdependent world," Harper row, New York, 1989.

[3] P.C. Aka, "The military and democratization in Africa," vol. 16, Journal of Third World Studies, 1999, pp. 73-73.

[4] H.N. Jun, "Military Politics and Democratization in Indonesia," Routledge curzon, London, 2003.

[5] P.C. Aka, "The military and democratization in Africa," vol. 16, Journal of Third World Studies, 1999, pp. 74-74.

[6] S.P. Huntington, "The soldier and the state," Harvard university press, Cambridge, 1957.

[7] K.Y. Hlaing, "Myanmar in 2003: frustration and despair?" vol. 44, Asian Survey, 2004, pp. 91-92.

[8] K.Y. Hlaing, "Myanmar in 2003: frustration and despair?" vol. 44, Asian Survey, 2004, pp. 90-90.

[9] K.Y. Hlaing, "Myanmar in 2003: frustration and despair?" vol. 44, Asian Survey, 2004, pp. 88-88.

[10] K.Y. Hlaing, "Myanmar in 2003: frustration and despair?" vol. 44, Asian Survey, 2004, pp. 175-175.

[11] A. Naw, "Aung San and the struggle for Burmese independence," Nordic Institute of Asian Studies, Copenhagen, 2001.

[12] "Than Shwe delivered an address at the 52nd anniversary armed forces day," The New Light of Myanmar, March 1997.

[13] "Than Shwe delivered an address at the 55th anniversary armed forces day parade," The New Light of Myanmar, 28 March 2000.

[14] M.A. Myoe, "The soldier and the state: the Tatmadaw and political liberalization in Myanmar," vol. 22, Southeast Asia Research, 2014, pp. 245-246.

[15] S. McCarthy, "Prospects for justice and stability Burma," vol. 46, Asian Survey, 2006, pp. 426-426.

[16] K.Y. Hlaing, "Power and factional struggle in post-independenc Burmese government," vol. 39, Journal of Southeast Asia Studies, 2008, pp. 173-173.

[17] B. Rogers, "Than Shwe: unmasking Burma`s tyrant," Silkworm books, Chiang Mai, 2010. 
[18] K.Y. Hlaing, "Power and factional struggle in post-independence Burmese government," vol. 39, Journal of Southeast Asia Studies, 2008, pp. 169-169.

[19] K.Y. Hlaing, "Myanmar in 2003: frustration and despair?" vol. 44, Asian Survey, 2004, pp. 89-89.

[20] R. Egreteau and L. Jagan, "Soldiers and diplomacy in Burma: understanding the foreign relations of the Burmese praetorian state," NUS press, Singapore, 2013.

[21] M.A. Myoe, "The soldier and the state: the Tatmadaw and political liberalization in Myanmar," vol. 22, Southeast Asia Research, 2014, pp. 244-244.

[22] M.A. Myoe, "The soldier and the state: the Tatmadaw and political liberalization in Myanmar," vol. 22, Southeast Asia Research, 2014, pp. 244-255.

[23] M.A. Myoe, "The soldier and the state: the Tatmadaw and political liberalization in Myanmar," vol. 22, Southeast Asia Research, 2014, pp. 255-255.

[24] B. Rogers, "Than Shwe: unmasking Burma's tyrant," Silkworm books, Chiang Mai, 2010.

[25] H.N. Jun, "Military politics and democratization in Indonesia," Routledge curzon, London, 2003.

[26] J. Bird, "Indonesia in 1997: the tinderbox year," vol. 38, Asian Survey, 1998, pp. 176-176.

[27] H.N. Jun, "Military politics and democratization in Indonesia," Routledge curzon, London, 2003.

[28] A. Rabasa and J. Haseman, "The military and democracy in Indonesia: challenges, politics, and power," RAND corporation, Santa Monica, 2002 .
[29] A. Rabasa and J. Haseman, "The military and democracy in Indonesia: challenges, politics, and power," RAND corporation, Santa Monica, 2002.

[30] H.N. Jun, "Military politics and democratization in Indonesia," Routledge curzon, London, 2003.

[31] A. Rabasa and J. Haseman, "The military and democracy in Indonesia: challenges, politics, and power," RAND corporation, Santa Monica, 2002.

[32] A. Rabasa and J. Haseman, "The military and democracy in Indonesia: challenges, politics, and power," RAND corporation, Santa Monica, 2002.

[33] M. Mietzner, "Military politics, Islam, and the state in Indonesia: from turbulent transition to democratic consolidation," Institute of Southeast Asian Studies, Singapore, 2009.

[34] F.S. Sun, "The resignation of Soeharto and its influences," Foreign Policy Review, 1998, pp. 48-48.

[35] M. Mietzner, "Military politics, Islam, and the state in Indonesia: from turbulent transition to democratic consolidation," Institute of Southeast Asian Studies, Singapore, 2009.

[36] H.N. Jun, "Military politics and democratization in Indonesia," Routledge curzon, London, 2003.

[37] H. James, "Myanmar in 2005: in a holding pattern," vol. 46, Asian Survey, 2006, pp. 62-62.

[38] M.A. Myoe, "Myanmar in 2006: another year of housekeeping?" vol. 47, Asian Survey, 2007, pp. 195-195.

[39] M.A. Myoe, "Myanmar in 2006: another year of housekeeping?" vol. 47, Asian Survey, 2007, pp. 195-195.

[40] H.Y. Zaw, "Myanmar ruling party chief sacked in power struggle with president," Reuters, August 2015. 